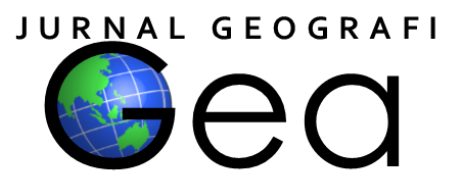

\title{
PERKEMBANGAN KAWASAN PERKOTAAN KECIL DI PINGGIRAN KOTA PEKALONGAN
}

\author{
Fadjar Hari Mardiansjah ${ }^{1}$, Paramita Rahayu ${ }^{2}$ \\ ${ }^{1}$ Departemen Perencanaan Wilayah dan Kota, Universitas Diponegoro, Semarang \\ ${ }^{2}$ Program Studi Perencanaan Wilayah dan Kota, Universitas Sebelas Maret, Surakarta \\ ${ }^{1}$ fadjarmardiansjah@lecturer.undip.ac.id, ${ }^{2}$ paramitarahayu@ @ staff.uns.ac.id
}

\begin{abstract}
The growing of peri-urban regions has been characterized urbanization process of cities in Java including in both large and much smaller ones. This paper uses villages' monograph data from 1990 to 2017 to present the extent to which peri-urban development has been occurring in Pekalongan region, as an elaboration of such process in a small city in Java, the densest populated big islands in the world. The study reveals peri-urban development process also happen in Pekalongan Region that shows as an extended urbanization phenomenon from the core to the surroundings peripheries. The elaboration shows peri-urban development in this region is highly concentrated along the national road of Pantura that form a more than $40 \mathrm{~km}$ urban corridor. Long term analysis shows the influence of the regional road network as well as the availability of the previous urban centers in the peripheries of Pekalongan City bring strong support to the extended formation of Pekalongan Urban Region. The paper concludes with a discussion of the policy implications of the findings.
\end{abstract}

Keywords: Java, peri-urbanization, spatial pattern, urban population growth.

\begin{abstract}
ABSTRAK
Perkembangan kawasan peri-urban telah menjadi karakteristik penting pada proses urbanisasi kota-kota di Jawa, baik pada kota-kota yang berukuran besar maupun kecil. Tulisan ini mempergunakan data monografi desa-desa dari tahun 1990 hingga 2017 untuk mempresentasikan sejauh mana perkembangan kawasan peri-urban terjadi di Kawasan Pekalongan, sebagai suatu pemahaman terhadap proses tersebut dalam proses urbanisasi yang terjadi pada suatu kota yang berukuran kecil di Jawa, yang merupakan pulau besar yang memiliki kepadatan penduduk tertinggi di dunia. Penelitian ini mengungkapkan bahwa proses perkembangan kawasan peri-urban juga terjadi pada Kawasan Pekalongan, yang memperlihatkan suatu fenomena perkembangan kawasan perkotaan yang meluas dari kawasan inti ke kawasan pinggiran di sekitarnya. Analisis memperlihatkan bahwa perkembangan peri-urban di kawasan ini sangat terkonsentrasi di sepanjang jalan nasional Patura, yang membentuk suatu koridor perkotaan lebih dari $40 \mathrm{~km}$. Analisis jangka panjang memperlihatkan bahwa keberadaan jalan regional utama dan keberadaan pusat-pusat aktivitas perkotaan pada kawasan pinggiran Kota Pekalongan telah memberikan dukungan kuat terhadap pembentukan kawasan koridor perkotaan ini. Tulisan ini ditutup oleh sebuah diskusi implikasi kebijakan dari temuantemuan yang dihasilkan.
\end{abstract}

Kata kunci: Jawa, periurbanisasi, pertumbuhan penduduk perkotaam, pola spasial. 


\section{PENDAHULUAN}

Pulau Jawa merupakan pulau besar terkecil di Indonesia, dengan luas sekitar 7\% dari luas daratan nasional. Namun, berdasarkan perkiraan Survey Penduduk Antar-Sensus (SUPAS) terakhir di tahun 2015, pulau ini merupakan kawasan tempat terkonsentrasinya 145,01 juta penduduk, yang merupakan $56,8 \%$ dari 255,2 juta penduduk Indonesia di tahun tersebut (BPS, 2015). Besarnya jumlah penduduk yang ada membuat kepadatan rata-rata di pulau ini menjadi 1.115 jiwa $/ \mathrm{km}^{2}$, sebagai tingkat kepadatan penduduk yang tertinggi dan jauh lebih tinggi daripada tingkat kepadatan penduduk nasional di tahun yang sama, sebesar 129,8 jiwa/ $\mathrm{km}^{2}$. Tingkat kepadatan penduduk tersebut juga membuat Jawa, yang merupakan pulau terbesar ke-13 di dunia, menjadi pulau besar terpadat di dunia setelah Honshu yang merupakan pulau terbesar ketujuh di dunia dengan kepadatan penduduk sekitar 447 jiwa/ $\mathrm{km}^{2}$ di tahun 2017.

Tingginya kepadatan penduduk tersebut mendorong Jawa menjadi kawasan yang subur bagi pertumbuhan penduduk dan kawasan perkotaan. SUPAS 2015 memperkirakan 90,83 juta atau $62,63 \%$ darri 145,0 juta penduduk Jawa tergolong kepada penduduk perkotaan, dimana jumlah tersebut mengkontribusi sebesar $66,97 \%$ dari seluruh peduduk perkotaan Indonesia. Jawa juga merupakan kawasan pertumbuhan perkotaan utama di Indonesia. Walau jumlah daerah kotanya relatif tidak banyak berubah, Jawa menyumbang tujuh dari sepuluh kota terbesar di Indonesia (Rahayu dan Mardiansjah, 2019). Namun, pertumbuhan kawasan perkotaan di Jawa tidak hanya terjadi di daerah-daerah kotanya saja. Pertumbuhan penduduk dan kawasan perkotaannya juga terjadi pada wilayah kabupaten-kabupaten, baik yang bersebelahan dengan daerah kota maupun tidak (Mardiansjah, 2013). Dengan menggunakan kasus pada Jawa Tengah dan Kawasan Segitiga Pertumbuhan Joglo Semar (Yogyakarta-Surakarta-Semarang dan sekitarnya), Setyono dkk (2016) juga menjelaskan besarnya proses pertumbuhan kawasan perkotaan (urbanisasi) yang terjadi di wilayah dari kabupaten-kabupaten yang berlokasi di antara ketiga kota tersebut.

Firman (2003) berpendapat bahwa pertumbuhan penduduk perkotaan di Pulau Jawa menunjukkan pola spasial yang melebar (extended metropolitan regions) telah dimulai sejak tahun 1980an. Perkembangan ini yang ditandai oleh melambatnya pertumbuhan penduduk perkotaan di daerah-daerah kota yang ada, serta meningkatnya laju pertumbuhan penduduk perkotaan di wilayah kabupaten-kabupaten sekitarnya (Firman, 2003, lihat juga Firman dkk, 2007, dan Firman, 2016). Berdasarkan observasinya pada beberapa kota Asia di India, Jepang, Cina dan Thailand, di tahun 1950an dan 1960an, Ginsburg (1991) menjelaskan bahwa perkembangan formasi kawasan perkotaan yang meluas ini merupakan suatu karakteristik spasial dari proses urbanisasi pada kota-kota utama di Asia, yang sangat berbeda dengan pola yang terjadi pada proses urbanisasi yang terjadi sebelumnya di Eropa dan di Amerika. Ginsburg (1991) mengatakan proses ini sebagai suatu proses urbanisasi pedesaan (urbanization of the countryside).

McGee (1991) mengatakan bahwa perkembangan kawasan perkotaan yang melebar merupakan salah satu karakter penting dari proses urbanisasi di Pulau Jawa. Beliau merumuskan pendapatnya tersebut dalam konsep "desakota" yang menggambarkan suatu kawasan padat penduduk di kawasan pinggiran kota yang berdekatan dan terhubung kepada kawasan inti atau pusat konsentrasi utama dari penduduk dan aktivitas kota, yang mencerminkan suatu proses dan karakteristik perubahan fisik, sosial dan ekonomi yang membawa dan mengarahkan kepada pembentukan suatu metropolitan besar (Mc Gee, 1971, lihat juga McGee, 2005). Oleh karena itu, ketimbang mengatakannya sebagai suatu urbanisasi pedesaan, McGee (1991) memilih mengatakannya sebagai suatu continuous urbanization, yaitu suatu pola urbanisasi yang menerus di dalam suatu transisi ruang-ekonomi (space-economy transition). Hal yang menarik menurut McGee adalah bahwa bentukan kawasan perkotaan yang melebar ini memperlihatkan 
suatu sistem spasial perkotaan yang melebar, yang mengaburkan batas-batas di antara kota dengan kawasan perdesaan di sekitarnya, yang juga membangun integrasi spasial di antara keduanya (McGee, 1991).

Perkembangan teknologi, terutama teknologi transportasi dan telekomunikasi, pasca perang dunia kedua telah meningkatkan konektivitas antara banyak kota di Asia dengan kawasan perdesaan di sekitarnya dan memfasilitasi sirkulasi orang/tenaga kerja dan barang-barang komoditas serta ide dan modal di atara kawasan metropolitan tersebut (McGee, 1991). Kondisi ini tidak hanya mempersilahkan tenaga kerja untuk tetap tinggal di kawasan pinggiran ketika memperoleh pekerjaan non pertanian di kota, tetapi juga memungkinkan keluarga-keluarga di kota untuk bertempat tinggal di pingggiran dengan tetap mempertahankan aktivitas dan pekerjaannya di kota.

Dalam perkembangannya di Pulau Jawa, pola pertumbuhan kawasan perkotaan melebar ini tidak hanya terjadi pada kawasankawasan perkotaan (metropolitan) besar seperti Jakarta, Bandung, Surabaya, Semarang dan Malang saja (Prawatya, 2013). Pada saat ini pola perkembangan spasial ini juga telah terjadi pada kawasan-kawasan perkotaan yang jauh lebih kecil seperti pada Kawasan Cirebon (Fahmi dkk, 2014) dan Kawasan Tegal (Mardiansjah, 2020). Selain itu, pola spasial pertumbuhan perkotaan yang melebar juga terjadi pada kawasan kota-kota menengah yang ada di Jawa seperti pada Kota Surakarta (Mardiansjah dkk, 2018; lihat juga Pradoto dkk , 2018) dan Malang (Mardiansjah, 2013).

Firman (2016) menjelaskan bahwa perluasan kawasan perkotaan melebar ini tidak saja diakibatkan oleh perluasan kawasan terbangun, tetapi juga sangat dipengaruhi oleh terjadinya reklasifikasi desa-desa yang ada di pinggiran kota inti dari desa non-perkotaan menjadi desa perkotaan. Dalam konteks ini, Firman dan Fahmi (2017) mengatakan bahwa proses perkembangan melebar merupakan proses urbanisasi in-situ yang mengubah desa-desa di pinggiran menjadi desa-desa perkotaan sehingga mengakibatkan terjadiya perluasan kawasan perkotaan yang melampaui batas wilayah administrasi kotanya ke kawasan pinggiran. Biasanya, desa-desa yang tereklasifikasi ini tidak saja memiliki kawasan-kawasan permukiman perkotaan yang padat penduduk saja di dalamnya. Seringkali desa-desa ini juga kawasan permukiman dengan kepadatan rendah, seperti permukiman pedesaan, yang terkombinasi dengan perkembangan signifikan dari aktivitas-aktivitas perkotaan di dalamnya, seperti kegiatan industri dan/atau perdagangan. Dalam proses ini, terjadi perubanan karakter fisik kawasan pinggiran yang mengkaburkan batasan antara perkotaan dan perdesaan akibat dari perkembangan kawasan campuran perkotaan dan perdesaan (Dutta dkk, 2013). Dealam konteks yang lebih luas, perkembangan pola spasial periurbanisasi akibat dari pertumbuhan spasial yang melebar (extend) dan/atau meloncat (sprawl) ke kawasan pinggiran ini sering membentuk suatu wilayah perkotaan (urban region) yang sangat luas dan jauh lebih luas daripada batas administrasi dari kota intinya (Dutta dkk, 2013).

Dutta dkk (2013) menjelaskan bahwa kawasan periurbanisasi seperti ini sering dihadapkan pada beberapa masalah penting dalam perkembangan perkotaannya, yang meliputi tekanan besar kepada kondis lingkungannya, perkembangan kawasan kumuh, rendahnya ketersediaan infrastruktur lingkungan dan sanitasi, hingga kepada masalah tekanan migrasi akibat dari rendahnya kemampuan dan kapasitas perencanaan yang ada. Tacoli (2006) dan McGregor dkk (2006) mengatakan bahwa rendahnya kemampuan perencanaan di kawasan peri-urban diakibatkan oleh karakteristik kawasan yang berada di luar juridiksi dann administrasi kota, sehingga umumnya kawasan seperti ini menjadi kawasan yang informal dan tak terencana, walaupun umumnya memiliki aktivitas dan pelayanan perkotaan.

Artikel ini ditujukan untuk melengkapi pemahaman tentang pola spasial pertumbuhan perkotaan melebar pada kawasan perkotaan yang berbasis pada kota kecil di Jawa, dengan melakukan elaborasi pada perkembangan kawasan perkotaan di sekitar Kota Pekalongan. Kota Pekalongan bisa 
dikategorikan sebagai kota kecil-menengah dengan jumlah penduduk sekitar 300 ribu jiwa. Kota ini yang terletak di jalur/koridor jalan regional Pantura (pantai utara) Jawa Tengah, dengan jarak sekitar $100 \mathrm{~km}$ dari Semarang ke arah barat. Pemahaman terhadap pola spasial perkembangan kawasan perkotaan di Pulau Jawa ini sangat penting, karena Pulau Jawa merupakan tempat terkonsentrasinya pemduduk perkotaan Indonesia, yang hingga kini masih menampung dua per tiga penduduk perkotaan nasional. Selain itu, pemahaman yang baik terhadap proses urbanisasi, termasuk pembentukan struktur dan pola spasialnya, akan bermanfaat bagi perumusan kebiijakan dan strategi pengelolaan urbanisasi dan perkembangan perkotaan di Jawa, yang diperkirakan akan terus menjadi salah satu tantangan pembangunan perkotaan nasional hingga beberapa dekade mendatang. Besarnya jumlah dan proporsi penduduk perkotaan di Jawa saat ini dan masa depan membuat masa depan perkotaan di Jawa akan memberikan pengaruh yang sangat besar kepada masa depan perkotaan di Indonesia.

\section{METODE PENELITIAN}

Penelitian ini dilakukan dengan menggunakan studi kasus perkembangan kawasan perkotaan kecil yang terjadi di pinggiran Kota Pekalongan untuk memperlihatkan fenomena urbanisasi yang menyebar di kawasan pinggiran dari suatu kota yang berukuran kecil-menengah di Pulau Jawa. Pengamatan terhadap perkembangan kawasan perkotaan kecil ini dilakukan dengan mengamati perkembangan kawasan-kawasan perkotaan yang tumbuh dan berkembang pada tiga buah kabupaten yang berada dalam radius sekitar 40 - $50 \mathrm{~km}$ dari Kota Pekalongan, yaitu: Kabupaten Pekalongan, Kabupaten Batang dan Kabupaten Pemalang, yang masing-masing beribukotakan di Kecamatan Kajen, Kecamatan Batang dan Kecamatan Pemalang. Jarak $40 \mathrm{~km}$ tersebut merupakan setengah jarak dari Kota Pekalongan ke Kota Tegal yang berada $80 \mathrm{~km}$ dari Kota Pekalongan ke barat, sementara jarak $50 \mathrm{~km}$ merupakan setengah jarak dari Kota Pekalongan ke Kota Semarang yang berlokasi sekitar $100 \mathrm{~km}$ dari Kota Pekalongan ke timur. Kabupaten Pekalongan dan Kabupaten Batang terletak bersebelahan dengan Kota Pekalongan, sementara Kabupaten Pemalang terletak di sebelah barat kota tersebut. Karena lokasi Kabupaten Pekalongan dan Pemalang berada pada kawasan pinggiran sebelah barat dan selatan, maka kedua kabupaten tersebut dikategorikan sebagai kawasan pinggiran barat, sementara Kabupaten Batang diklasifikasi sebagai pinggiran timur karena lokasinya yang berada di sebelah timur Kota Pekalongan.

Pengamatan terhadap kawasankawasan perkotaan di kawasan pinggiran ini dilakukan melalui mengamati perkembangan desa-desa perkotaan di kabupaten-kabupaten sekitar, yang diklasifikasi oleh BPS secara berkala, terutama pada tahun dilaksanakannya Sensus Penduduk yaitu tahun 1980, 1990, 2000 dan 2010, serta tahun 2017 sebagai data tahun terakhir BPS melakukan klasifikasi desa perkotaan dan non-perkotaan hingga saat ini. Selain mengamati jumlah desa perkotaan yang tergabung di dalam setiap aglomerasi perkotaan, indentifikasi kawasan perkotaan ini juga memperhatikan besaran penduduk yang berada di dalam setiap aglomerasi perkotaan yang terbentuk dan berkembang. Identifikasi kawasan perkotaan dilakukan dengan mengamati aglomerasi desa-desa perkotaan yang ada di setiap tahun amatan dengan menggunakan dua variable, yaitu lokasi/posisi desa perkotaan dan batas kecamatan. Desa-desa perkotaan yang bersebelahan di dalam kecamatan yang sama dianggap membentuk suatu kawasan perkotaan yang sama, namun desa-desa perkotaan yang bersebelahan tetapi berasal dari kecamatan yang berbeda dianggap merupakan kawasan perkotaan yang berbeda. Selanjutnya, aglomerasi desa-desa perkotaan yang membentuk kawasan-kawasan perkotaan itu diklasifikasi ke dalam empat kategori kawasan perkotaan berdasarkan jumlah penduduknya, yaitu: (1) kawasan perkotaan besar dengan lebih dari 100 ribu penduduk; (2) kawasan perkotaan sedang dengan penduduk antara 30.000 - 100.000 jiwa; dan (3) kawasan perkotaan kecil dengan penduduk kurang dari 30.000 jiwa. 
Analisis dan pengamatan terhadap perkembangan kawasan perkortaan kecil ini juga mempertimbangkan pola spasial dari aglomerasi atau kawasan-kawasan perkotaan yang terbentuk dan berkembang. Analisis ini dilakukan dengan mengamati posisi dan pola lokasi dari kawasan-kawasan perkotaan yang berkembang terhadap dua buah acuan lokasi utama, yaitu Kota Pekalongan sebagai kawasan inti dari kawasan perkotaan besar (urban region) yang terbangun, dan keberadaan elemen-elemen spasial penting yang berpengaruh terhadap pertumbuhan dan perkembangan perkotaan, yaitu infrastruktur transportasi regional utama yang ada, terutama jaringan Jalan Nasional Pantura (Pantai Utara) Jawa. Diharapkan analisis lokasi ini juga mampu memberikan penjelasan terhadap perkembangan kawasankawasan perkotaan kecil tersebut.

\section{HASIL DAN PEMBAHASAN}

\section{Perkembangan Penduduk Perkotaan di Kawasan Pekalongan}

Hasil Sensus Penduduk Nasional beberapa dekade terakhir memperlihatkan bahwa Kawasan Pekalongan telah menjadi kawasan tempat berlokasinya pertumbuhan penduduk perkotaan yang pesat (lihat Tabel 1). Pada antara tahun 1980 hingga 2010, penduduk perkotaan di kawasan ini tumbuh dengan laju pertumbuhan rata-rata sebesar $3,7 \%$ per tahun, sedangkan rata-rata laju pertumbuhan penduduk totalnya di periode yang hanya sebesar $0,9 \%$ per tahun. Laju pertumbuhan penduduk perkotaan tertinggi terjadi pada periode 1980an, yaitu sebesar $5,1 \%$ per tahun yang kemudian sedikit menurun pada dekade 1990an dengan ratarata sebesar $4,9 \%$ per tahun. Pasca tahun 2000, laju pertumbuhannya melambat drastis dengan rata-rata antara $1,2 \%$ per tahun antar. Sebagai salah satu implikainya, hasil Sensus Penduduk di tahun 2010 telah mengkonfirmasi bahwa lebih dari setengah penduduk kawasan ini merupakan penduduk perkotaan dengan tingkat urbanisasi sebesar 53,06\%, walaupun di tahun 1980 angka proporsi tersebut baru mencapai 23,42\%. Dengan demikian, masyarakat di kawasan yang terbentuk oleh Kota Pekalongan dan tiga kabupaten di sekitarnya ini telah mulai dapat dikategorikan sebagai masyarakat perkotaan.

Pada dasarnya, rata-rata laju pertumbuhan penduduk total di kawasan pinggiran $(0,8 \%$ per tahun) masih sedikit lebih rendah daripada rata-rata lajunya di kawasan pusat, yaitu Kota Pekalongan (0,9\% per tahun). Namun, pertumbuhan penduduk perkotaan yang terjadi sangat berbeda dengan pertumbuhan penduduk totalnya. Kawasan pinggiran memiliki rata-rata laju pertumbuhan penduduk perkotaan tahunan sebesar 4,0\% per tahun pada antara 1980 hingga 2010, sedangkan kawasan pusat hanya sebesar 2,5\% per tahun di periode yang sama.

Laju pertumbuhan tinggi di kawasan pusat hanya terjadi pada periode 1980an dengan angka sebesar 6,3\% per tahun sebagai akibat adanya perubahan definisi penduduk perkotaan di wilayah daerah kota, atau kotamadya pada terminologinya di masa lalu, dari hanya penduduk kelurahan-kelurahan yang berkarakter fisik perkotaan menurut definisinya di Sensus Penduduk Tahun 1980 menjadi seluruh penduduk di wilayah kotamadya menurut definisinya pada Sensus Penduduk tahun 1990. Pada periode selanjutnya, Kota Pekalongan hanya memiliki rata-rata laju pertumbuhan penduduk perkotaan antara $0,7 \%$ hingga $0,9 \%$ per tahun. Sementara itu, kawasan pinggiran memiliki laju pertumbuhan tinggi sebesar $4,7 \%$ per tahun pada dekade 1980an dan $6,1 \%$ pada dekade 1990an, walau kemudian melambat ke angka $1,3 \%$ per tahun pada dekade 2000an dan sedikit meningkat menjadi $1,5 \%$ per tahun pada antara tahun 2010 hingga 2017.

Di antara kedua kawasan pinggiran, kawasan pinggiran timur (Kabupaten Batang) yang berada di antara Kota Pekalongan dan Kota Semarang, merupakan kawasan yang memiliki laju pertumbuhan penduduk perkotaan yang lebih tinggi (4,8\% per tahun) daripada yang terjadi di pinggiran barat $(3,8 \%$ per tahun). Bahkan laju pertumbuhan penduduk total di Kabupaten Batang juga lebih tinggi daripada laju pertumbuhan kedua kabupaten yang berada di kawasan barat. Namun pola pertumbuhan tinggi di kabupaten ini berbeda dengan yang terjadi di kedua 
kabupaten pinggiran barat. Laju laju pertumbuhan sangat tinggi Kabupaten Batang ( $8,1 \%$ per tahun) terjadi pada tahun 1980an yang kemudian melambat menjadi $3,6 \%$ per tahun pada dekade 1990an. Sementara itu, kedua kabupaten di pinggiran barat, yaitu Kabupaten Pekalongan dan Pemalang, memiliki laju pertumbuhan sangat tinggi (masing-masing 6,5\% per tahun dan 7,0\% per tahun) pada dekade 1990an setelah pertumbuhan yang lebih lambat $(3,2 \%$ dan
$4,2 \%$ per tahun) pada dekade sebelumnya. Selain itu, berbeda dengan kawasan barat yang telah sangat melambat sehingga hanya memiliki laju pertumbuhan penduduk perkotaan antara $1,0 \%$ hingga $1,3 \%$ per tahun pada paska tahun 2000an hingga 2017, Kabupaten Batang masih memiliki laju pertumbuhan penduduk perkotaan yang cukup tinggi dengan angka rata-rata sebesar $2,1 \%$ hingga $2,8 \%$ per tahun pada perioda yang sama.

Tabel 1. Pertumbuhan Penduduk Total dan Penduduk Perkotaan di Kawasan Pekalongan, Tahun 1980 hingga 2017

\begin{tabular}{|c|c|c|c|c|c|}
\hline Wilayah/Kawasan & $1980 *$ & 1990* & $2000 *$ & 2010* & $2017 * *$ \\
\hline \multicolumn{6}{|c|}{ Jumlah Penduduk Total } \\
\hline Kawasan Pekalongan & $2,341,397$ & $2,648,559$ & $2,983,016$ & $3,088,172$ & $3,207,498$ \\
\hline Kota Pekalongan & 213,917 & 242,874 & 262,272 & 281,434 & 301,870 \\
\hline Kawasan Pinggiran & $2,127,480$ & $2,405,685$ & $2,720,744$ & $2,806,738$ & $2,905,628$ \\
\hline - Kawasan Pinggiran Barat & $1,597,063$ & $1,814,038$ & $2,059,640$ & $2,099,974$ & $2,162,538$ \\
\hline - Kab. Pekalongan & 651,645 & 699,810 & 798,186 & 838,621 & 873,972 \\
\hline - Kab. Pemalang & 945,418 & $1,114,228$ & $1,261,454$ & $1,261,353$ & $1,288,566$ \\
\hline - Kawasan Pinggiran Timur & 530,417 & 591,647 & 661,104 & 706,764 & 743,090 \\
\hline - Kab. Batang & 530,417 & 591,647 & 661,104 & 706,764 & 743,090 \\
\hline \multicolumn{6}{|c|}{ Jumlah Penduduk Perkotaan } \\
\hline Kawasan Pekalongan & 548,284 & 899,276 & $1,452,030$ & $1,638,585$ & $1,779,719$ \\
\hline Kota Pekalongan & 132,413 & 242,874 & 262,272 & 281,434 & 301,870 \\
\hline Kawasan Pinggiran & 415,871 & 656,402 & $1,189,758$ & $1,357,151$ & $1,477,849$ \\
\hline - Kawasan Pinggiran Barat & 345,590 & 502,797 & 971,672 & $1,070,507$ & $1,179,348$ \\
\hline - Kab. Pekalongan & 138,470 & 190,109 & 355,879 & 433,530 & 450,154 \\
\hline - Kab. Pemalang & 207,120 & 312,688 & 615,793 & 636,977 & 729,194 \\
\hline - Kawasan Pinggiran Timur & 70,281 & 153,605 & 218,086 & 286,644 & 298,501 \\
\hline - Kab. Batang & 70,281 & 153,605 & 218,086 & 286,644 & 298,501 \\
\hline
\end{tabular}

Sumber: * Diolah berdasarkan data hasil Sensus Penduduk tahun 1980, 1990, 2000 dan 2010

** Diolah berdasarkan data jumlah penduduk setiap desa perkotaan dari yang yang tercantum padaKecamatan dalam Angka Tahun 2018.

Dari sisi jumlah, laju pertumbuhan penduduk perkotaan yang cepat telah menjadikan jumlah penduduk perkotaan di Kawasan Pekalongan menjadi sekitar tiga kali lipat jumlahnya di tahun 1980, dengan pertambahan penduduk perkotaan di kawasan pinggiran yang jauh lebih banyak dari pada yang terdapat di kawasan pusat. Kawasan pinggiran memperoleh hamper satu juta penduduk perkotaan baru selama periode 30 tahun tersebut, dimana kawasan pusat hanya memiliki sekitar 150 ribu penduduk perkotaan baru pada rentang waktu yang sama. Dari sekitar satu juta jiwa penduduk perkotaan tambahan di kawasan pinggiran, sekitar 700 ribu jiwa berasal dari kawasan pinggiran barat 
yang terbagi menjadi sekitar 300 ribu jiwa dari Kabupaten Pekalongan dan 400 ribu jiwa di Kabupaten Pemalang. Sementara itu pinggiran timur (Kabupaten Batang) memiliki sekitar 200 ribu jiwa penduduk perkotaan baru.

Dengan demikian, pertumbuhan peduduk perkotaan di kawasan ini telah membuat kawasan pinggiran Kota Pekalongan yang terdiri dari ketiga kabupaten tersebut menjadi tempat bermukimnya penduduk perkotaan. Bahkan, proporsi penduduk perkotaan yang bermukim di kawasan pinggiran semakin terus bertambah semakin besar daripada yang bermukim di kawasan pusat, Kota Pekalongan. Semakin besarnya jumlah penduduk perkotaan di kawasan pinggiran semakin menunjukkan peran kawasan pinggiran kawasan ini di

Tabel 2. Pertumbuhan Jumlah Desa Perkotaan di Kawasan Pinggiran Pekalongan

\begin{tabular}{lcccc}
\hline \multirow{2}{*}{ Kawasan/Kabupaten } & \multicolumn{5}{c}{ Jumlah Desa Perkotaan } \\
\cline { 2 - 5 } & $\mathbf{1 9 9 0}$ & $\mathbf{2 0 0 0}$ & $\mathbf{2 0 1 0}$ & $\mathbf{2 0 1 7}$ \\
\hline Kawasan Pinggiran Barat & $\mathbf{9 7}$ & $\mathbf{1 0 9}$ & $\mathbf{1 9 8}$ & $\mathbf{1 9 8}$ \\
- Kabupaten Pekalongan & 59 & 71 & 110 & 110 \\
- Kabupaten Pemalang & 38 & 38 & 88 & 88 \\
Kawasan Pinggiran Timur & $\mathbf{2 5}$ & $\mathbf{3 6}$ & $\mathbf{7 2}$ & $\mathbf{7 2}$ \\
- Kabupaten Batang & 25 & 36 & 72 & 72 \\
Total di Kawasan Pinggiran & $\mathbf{1 2 2}$ & $\mathbf{1 4 5}$ & $\mathbf{2 7 0}$ & $\mathbf{2 7 0}$ \\
\hline \multicolumn{5}{c}{ Sumber: Diolah dari hasil klasifikasi desa-desa perkotaan oleh BPS. }
\end{tabular}

Kawasan pinggiran Kota Pekalongan mengalami peningkatan jumlah desa perkotaan menjadi lebih dari dua kali lipat selama periode amatan, dari 122 desa perkotaan di tahun 1980 menjadi 270 desa perkotaan di tahun 2017. Sebenarnya setiap kabupaten memperoleh sekitar 50 desa perkotaan tambahan/baru selama kurun waktu tersebut. Namun, karena Kabupaten Batang merupakan kawasan yang memiliki paling sedikit desa perkotaan di tahun 1980, maka secara relatif kabupaten tersebut memiliki pertambahan yang paling tinggi yang membuatnya memiliki hampir tiga kali lipat desa perkotaan daripada jumlahnya di tahun 1980.

Sangat menarik untuk mengetahui bahwa pertambahan desa perkotaan baru yang terjadi setelah tahun 2000 jauh lebih besar daripada yang terjadi sebelum tahun 2000 . Secara total, kawasan pinggiran ini hanya dalam menampung penduduk perkotaan beserta perkembangannya.

\section{Perkembangan Kawasan Perkotaan di Kawasan Pekalongan}

Sebagaimana BPS memperhitungkan jumlah penduduk perkotaan di suatu wilayah berdasarkan jumlah penduduk yang tinggal di desa-desa perkotaan yang terdapat di wilayah tersebut, maka perkembangan jumlah penduduk perkotaan di ketiga kabupaten kawasan pinggiran tersebut juga mengindikasikan terjadinya perkembangan jumlah desa perkotaan yang terdapat di sana. Tabel 2 meperlihatkan perkembangan jumlah desa perkotaan di setiap wilayah pada kawasan pinggiran Kota Pekalongan yang terus meningkat dari tahun ke tahun. memiliki 23 buah desa perkotaan baru antara tahun 1990 ke 2000, dengan sebaran sebanyak 12 desa perkotaan baru di Kabupaten Pekalongan dan 11 desa perkotaan baru di Kabupaten Batang. Namun, jumlah pertambahan tersebut melonjak tinggi menjadi 125 buah desa perkotaan baru yang tersebar masing-masing sebanyak 39, 50 dan 36 desa di Kabupaten Pekalongan, Pemalang dan Batang. Mungkin kondisi ini memiliki keterkaitan dengan dilaksanakannya era otonomi daerah, sejak tahun 2000, yang memberikan kewenangan dan keleluasaan bagi setiap daerah di Indonesia, termasuk daerah-daerah kabupaten, untuk mengelola pertumbuhan dan pembangunannya secara mandiri.

Secara spasial, sebaran desa-desa perkotaan di ketiga wilayah kabupaten tersebut adalah seperti yang dapat dilihat pada Gambar 1 pada halaman berikut. Gambar 
tersebut memperlihatkan perkembangan desadesa perkotaan di ketiga wilayah kabupaten yang menjadi kawasan pinggiran dari Kota Pekalongan. Pada gambar tersebut, tampak bahwa perkembangan desa-desa perkotaan di ketiga kabupaten tersebut cenderung terkonsentrasi dan mengarah kepada pembentukan koridor perkotaan yang berbasis pada jaringan Jalan Nasional Pantura (Pantai Utara) Jawa, menjadi sebuah koridor perkotaan ysng bisa disebut sebagai Koridor Perkotaan Pemalang-Pekalongan-Batang. Koridor perkotaan ini dibentuk oleh Kota Pekalongan (301,9 ribu penduduk), sebagai kota inti atau kota utama yang berada di dalam koridor, beserta beberapa kawasan perkotaan yang berukuran cukup besar karena saat ini kawasan-kawasan perkotaan tersebut telah memiliki jumlah penduduk yang lebih dari 100 ribu jiwa di setiap kawasan perkotaannya, yaitu Pemalang (167,6 ribu penduduk) di yang berada ujung barat, dan diikuti oleh beberapa kawasan perkotaan besar lain di antara Pemalang dan Pekalongan, yaitu Kawasan Perkotaan Taman (122,6 ribu penduduk) dan Petarukan (126,3 ribu penduduk), hingga Kawasan Perkotaan Batang (111,6 ribu penduduk) berada di ujung timur, yang berlokasi di sebelah timur dari Kota Pekalongan. Di dalam Koridor perkotaan ini juga terdapat beberapa kawasan perkotaan lain yang berukuran lebih kecil, yang juga terletak di sepanjang jaringan Jalan Nasional Pantura, yaitu Comal (85,8 ribu penduduk), Ulujami (57,2 ribu penduduk), dan Wiradesa (49,2 ribu penduduk), dan sebuah kawasan perkotaan yang berukuran kecil yaitu Siwalan yang baru memiliki jumlah pemduduk sebesar 10,5 ribu penduduk, dan Tirto (60,6 ribu penduduk).

Hal yang menarik lain secara spasial adalah bahwa koridor perkotaan PemalangPekalongan-Batang ini juga telah memiliki sebuah “cabang' dari koridor perkotaan tersebut, dengan perkembangan beberapa kawasan perkotaan di sebelah selatan jalur jaringan Jalan Nasional Pantura, yaitu Buaran (46 ribu penduduk), Bojong (40,6 ribu penduduk) dan Kedungwuni (85 ribu penduduk). Dengan demikian, Kawasan Perkotaan Pemalang-Pekalongan-Batang ini mencakup 13 buah kawasan perkotaan yang meliputi 126 buah desa perkotaan di luar wilayah Kota Pekalongan dengan jumlah penduduk yang mencapai 1,01 juta jiwa penduduk perkotaan.

\section{Kawasan Perkotaan dengan Penduduk lebih dari 100 ribu Jiwa}

Hingga saat ini, telah terdapat empat kawasan perkotaan besar di kawasan pinggiran Kota Pekalongan yang memiliki jumlah penduduk lebih dari 100 ribu jiwa, yaitu Kawasan Perkotaan Pemalang, Petarukan, Taman dan Batang (lihat Tabel 2). Tiga kawasan perkotaan yang pertama tersebut merupakan kawasan-kawasan perkotaan yang terletak di wilayah Kabupaten Pemalang di sebelah barat Kota Pekalongan, sedangkan kawasan perkotaan yang terakhir berlokasi di Kabupaten Batang yang terletak bersebelahan di sebelah timur dengan Kota Pekalongan. Hal yang menarik untuk dicermati adalah bahwa kawasan-kawasan perkotaan terbesar di kedua wilayah tersebut, yaitu Pemalang dan Batang, merupakan kawasan-kawasan yang berperan sebagai ibukota dari masing-masing kabupaten. Kawasan-kawasan ini selalu merupakan kawasan perkotaan terbesar di kabupatennya masing-masing.

Seperti yang dijelaskan sebelumnya, keempat kawasan perkotaan terbesar di pinggiran Kota Pekalongan ini berlokasi di koridor jaringan Jalan Nasional Pantura, jaringan jalan regional terpenting di Pulau Jawa yang menghubungkan Jakarta dan Surabaya dan kota-kota besar dan kecil lain di Pantai Utara Jawa, seperti Cirebon, Tegal, Pekalongan dan Semarang. Ketiadaan kawasan perkotaan $\mathrm{Hal}$ ini memberikan indikasi bahwa lokasi kawasan yang berada di jalur regional utama memberikan pengaruh kepada kawasan-kawasan perkotaan tersebut untuk berkembang dan membesar. 


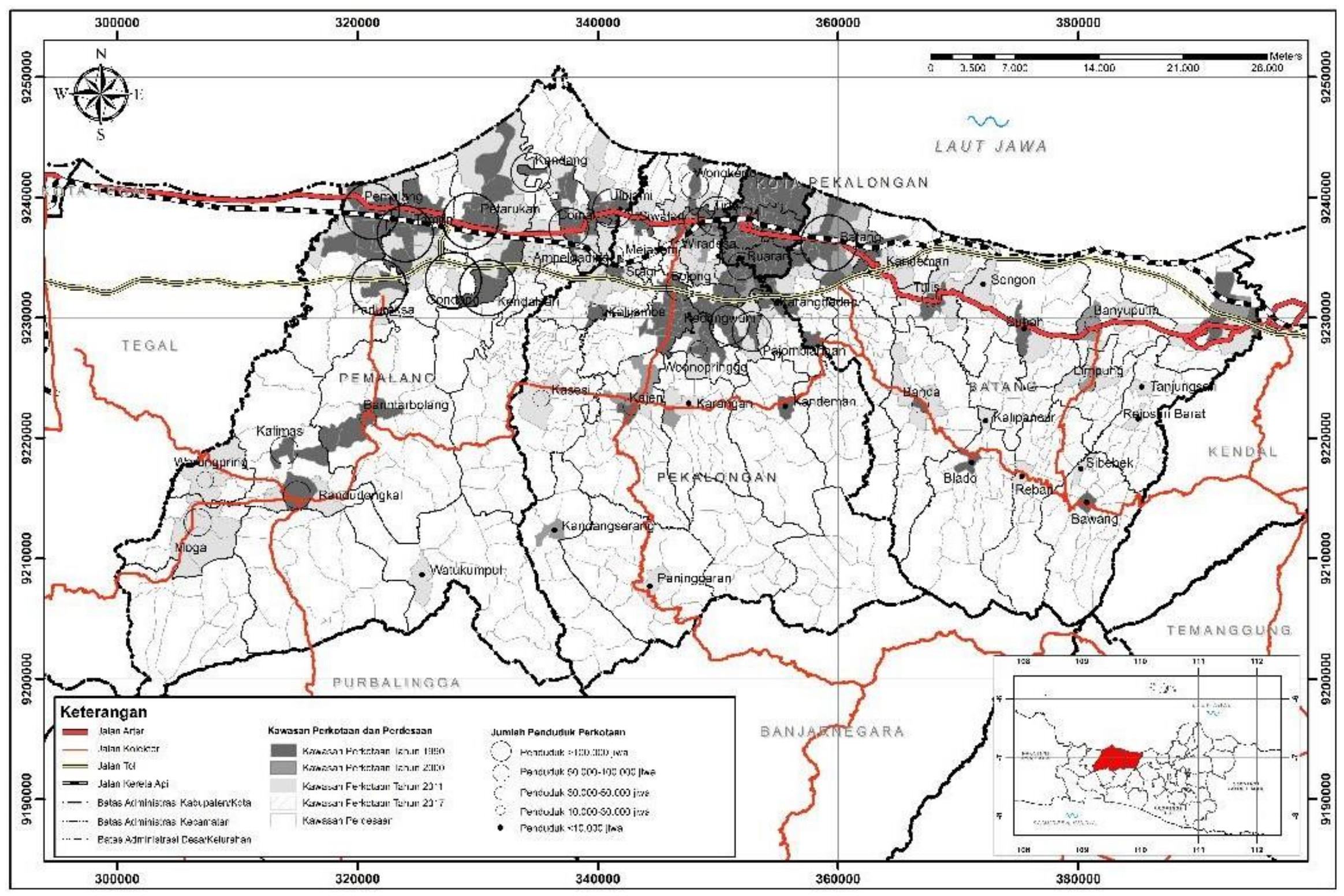

Sumber: Hasil Analisis, 2020.

Gambar 1. Perkembangan Kawasan Perkotaan di Pinggiran Kota Pekalongan. 
H. Mardiansjah, P. Rahayu. Perkembangan Kawasan Perkotaan ... 160

Tabel 2. Pertumbuhan Kawasan-kawasan Perkotaan Kecil dengan penduduk lebih dari 30 ribu jiwa, dari tahun 1990 hingga 2017

\begin{tabular}{|c|c|c|c|c|c|c|c|c|c|c|}
\hline \multirow[b]{2}{*}{ No. } & \multirow[b]{2}{*}{ Kecamatan } & \multirow[b]{2}{*}{ Kawasan Perkotaan (KP) } & \multicolumn{2}{|c|}{1990} & \multicolumn{2}{|c|}{2000} & \multicolumn{2}{|c|}{2010} & \multicolumn{2}{|c|}{2017} \\
\hline & & & $\begin{array}{c}\text { Jumlah } \\
\text { Desa }\end{array}$ & $\begin{array}{l}\text { Jumlah } \\
\text { Penduduk } \\
\text { (jiwa) }\end{array}$ & $\begin{array}{c}\text { Jumlah } \\
\text { Desa }\end{array}$ & $\begin{array}{l}\text { Jumlah } \\
\text { Penduduk } \\
\text { (jiwa) }\end{array}$ & $\begin{array}{c}\text { Jumlah } \\
\text { Desa }\end{array}$ & $\begin{array}{l}\text { Jumlah } \\
\text { Penduduk } \\
\text { (jiwa) }\end{array}$ & $\begin{array}{c}\text { Jumlah } \\
\text { Desa }\end{array}$ & $\begin{array}{l}\text { Jumlah } \\
\text { Penduduk } \\
\text { (jiwa) }\end{array}$ \\
\hline \multicolumn{11}{|c|}{ Kawasan-kawasan Perkotaan Kecil dengan penduduk lebih dari 100 ribu jiwa } \\
\hline \multirow[t]{2}{*}{1} & Pemalang (Pml) & KP Pemalang & 6 desa & 93,754 & 6 desa & 101,272 & 15 desa & 167,627 & 15 desa & 167,627 \\
\hline & & KP Paduraksa & 2 desa & 8,836 & 2 desa & 10,103 & - & - & - & - \\
\hline \multirow[t]{2}{*}{2} & Petarukan (Pml) & KP Petarukan & 5 desa & 45,001 & 5 desa & 54,150 & 14 desa & 126,341 & 14 desa & 126,341 \\
\hline & & KP Kendalsari & 2 desa & 16,415 & 2 desa & 18,757 & - & - & - & - \\
\hline \multirow[t]{2}{*}{3} & Taman (Pml) & KP Taman & 8 desa & 83,426 & 8 desa & 70,757 & 12 desa & 122,566 & 12 desa & 122,561 \\
\hline & & KP Gondang & - & - & - & - & 1 desa & 6,552 & 1 desa & 6,552 \\
\hline 4 & Batang (Btg) & Batang & 6 desa & 29,957 & 13 desa & 147,409 & 18 desa & 103,275 & 18 desa & 111,583 \\
\hline \multicolumn{11}{|c|}{ Kawasan-kawasan Perkotaan Kecil dengan penduduk antara $30-100$ ribu jiwa } \\
\hline \multirow[t]{2}{*}{1} & Kedungwuni (Pkl) & KP Kedungwuni & 8 desa & 48,585 & 9 desa & 67,143 & 15 desa & 82,656 & 15 desa & 84,888 \\
\hline & & KP Pajomblangan & 2 desa & 4,072 & 2 desa & 4,402 & - & - & - & - \\
\hline \multirow[t]{2}{*}{2} & Comal (Pml) & KP Comal & 8 desa & 38,639 & 8 desa & 44,163 & 16 desa & 134,811 & 16 desa & 85,811 \\
\hline & & KP Kandang & 1 desa & 3,800 & 1 desa & 3,800 & - & - & - & - \\
\hline 3 & Tirto (Pkl) & KP Tirto & 3 desa & 11,866 & 6 desa & 22,415 & 13 desa & 59,203 & 13 desa & 60,643 \\
\hline 4 & Ulujami (Pml) & KP Ulujami & 3 desa & 15,541 & 3 desa & 18,095 & 9 desa & 57,239 & 9 desa & 57,239 \\
\hline 5 & Wiradesa (Pkl) & KP Wiradesa & 6 desa & 20,699 & 8 desa & 29,120 & 12 desa & 47,270 & 12 desa & 49,180 \\
\hline 6 & Buaran (Pkl) & KP Buaran & 8 desa & 28,385 & 9 desa & 33,434 & 10 desa & 44,082 & 10 desa & 46,426 \\
\hline \multirow[t]{2}{*}{7} & Randudongkal (Pml) & KP Randudongkal & 1 desa & 16,473 & 1 desa & 18,991 & 5 desa & 43,972 & 5 desa & 43,972 \\
\hline & & KP Kalimas & 1 desa & 7,308 & 1 desa & 7,922 & - & - & - & - \\
\hline 8 & Bojong (Pkl) & KP Bojong & 15 desa & 32,966 & 15 desa & 37,375 & 15 desa & 39,846 & 15 desa & 40,632 \\
\hline 9 & $\operatorname{Moga}(\operatorname{Pml})$ & KP Moga & - & - & - & - & 5 desa & 41,986 & 5 desa & 41,986 \\
\hline 10 & Wonokerto (Pkl) & KP Wonokerto & 2 desa & 10,466 & 3 desa & 13,253 & 7 desa & 33,045 & 7 desa & 34,739 \\
\hline
\end{tabular}


Hal yang menarik lain secara spasial adalah bahwa koridor perkotaan PemalangPekalongan-Batang ini juga telah memiliki sebuah 'cabang' dari koridor perkotaan tersebut, dengan perkembangan beberapa kawasan perkotaan di sebelah selatan jalur jaringan Jalan Nasional Pantura, yaitu Buaran (46 ribu penduduk), Bojong (40,6 ribu penduduk) dan Kedungwuni (85 ribu penduduk). Dengan demikian, Kawasan Perkotaan Pemalang-Pekalongan-Batang ini mencakup 13 buah kawasan perkotaan yang meliputi 126 buah desa perkotaan di luar wilayah Kota Pekalongan dengan jumlah penduduk yang mencapai 1,01 juta jiwa penduduk perkotaan.

\section{Kawasan Perkotaan dengan Penduduk Lebih dari 100 ribu Jiwa}

Hingga saat ini, telah terdapat empat kawasan perkotaan besar di kawasan pinggiran Kota Pekalongan yang memiliki jumlah penduduk lebih dari 100 ribu jiwa, yaitu Kawasan Perkotaan Pemalang, Petarukan, Taman dan Batang (lihat Tabel 2). Tiga kawasan perkotaan yang pertama tersebut merupakan kawasan-kawasan perkotaan yang terletak di wilayah Kabupaten Pemalang di sebelah barat Kota Pekalongan, sedangkan kawasan perkotaan yang terakhir berlokasi di Kabupaten Batang yang terletak bersebelahan di sebelah timur dengan Kota Pekalongan. Hal yang menarik untuk dicermati adalah bahwa kawasan-kawasan perkotaan terbesar di kedua wilayah tersebut, yaitu Pemalang dan Batang, merupakan kawasan-kawasan yang berperan sebagai ibukota dari masing-masing kabupaten. Kawasan-kawasan ini selalu merupakan kawasan perkotaan terbesar di kabupatennya masing-masing.

Seperti yang dijelaskan sebelumnya, keempat kawasan perkotaan terbesar di pinggiran Kota Pekalongan ini berlokasi di koridor jaringan Jalan Nasional Pantura, jaringan jalan regional terpenting di Pulau Jawa yang menghubungkan Jakarta dan Surabaya dan kota-kota besar dan kecil lain di Pantai Utara Jawa, seperti Cirebon, Tegal, Pekalongan dan Semarang. Ketiadaan kawasan perkotaan $\mathrm{Hal}$ ini memberikan indikasi bahwa lokasi kawasan yang berada di jalur regional utama memberikan pengaruh kepada kawasan-kawasan perkotaan tersebut untuk berkembang dan membesar.

Tabel 2 memperlihatkan bahwa kawasan-kawasan perkotaan besar ini memiliki jumlah desa perkotaan yang cukup banyak, dengan rentang jumlah desa yang berkisar antara 12 hingga 18 desa perkotaan untuk setiap kawasannya. Banyaknya jumlah desa ini turut mempengaruhi besaran penduduk yang berada di dalam kawasan perkotaan tersebut. Selain itu, tampak bahwa peningkatan jumlah penduduk dari keempat kawasan perkotaan terbesar ini juga sangat dipengaruhi oleh bertambahnya jumlah desa perkotaan yang membentuk kawasan-kawasan perkotaan tersebut. Kawasan Perkotaan Pemalang berkembang dari enam buah desa perkotaan di tahun 1990 menjadi 15 buah desa perkotaan di tahun 2017. Perubahan jumlah desa perkotaan terjadi di antara tahun 2000 ke 2010, dari 6 desa menjadi 15 desa perkotaan, dengan turut menggabungkan dua buah desa perkotaan yang sebelumnya telah menjadi desa perkotaan tetapi tidak berada dalam aglomerasi yang sama dengan aglomerasi/kawasan perkotaan Pemalang. Kronologi serupa juga terjadi pada Kawasan Petarukan yang berkembang dari lima buah desa perkotaan di tahun 1990 menjadi 14 desa perkotaan, dengat turut menggabungkan dua buah desa lain di antara tahun 2000 ke 2010, ketika kawasan perkotaan ini mengalami pertambahan jumlah desa perkotaan terbesar. Kawasan Perkotaan Taman juga mengalami pertambahann jumlah desa perkotaan yang cukup besar dari 8 desa di tahun 1990 menjadi 12 desa di tahun 2010 dan 2017. Bahkan kawasan perkotaan ini juga memiliki desa perkotaan baru di sekitarnya, yang hingga saat belum tergabung ke dalam aglomerasi perkotaan yang sama. Penambahan jumlah desa terbesar terjadi pada Kawasan Perkotaan Batang dengan memiliki tambahan sebanyak 12 desa perkotaan dari 6 desa di tahun 1990 menjadi 18 desa di tahun 2017. Berbeda dengan kawasan perkotaan besar lain yang baru mengalami penambahan di antara tahun 2000 dan 2010, pertambahan yang terjadi di Kawasan Perkotaan Batang telah terjadi sejak antara tahun 1990 dan 2000 
yang terus bertambah banyak hingga ke tahun 2010. Besar kemungkinan bahwa kondisi ini dipengaruhi oleh lebih rendahnya tingkat urbanisasi yang dimiliki oleh Kabupaten Batang daripada Kabupaten Pemalang dan juga Pekalongan.

\section{Kawasan Perkotaan dengan Penduduk antara 30 - 100 ribu Jiwa}

Pada saat ini, juga terdapat sepuluh buah kawasan perkotaan sedang, dengan jumlah penduduk antara 30 - 100 ribu jiwwa di setiap kawasannya. Jumlah tersebut terbagi menjadi dua kelompok berdasarkan jumlah penduduknya, Kelompok pertama adalah empat kawasan perkotaan yaitu Kedungwuni, Comal, Tirto dan Ulujami yang dengan penduduk antara 50 - 100 ribu jiwa, dan kelompok kedua adalah enam kawasan yaitu Wiradesa, Buaran, Randudongkal, Bojong, Moga dan Wonokerto dengan penduduk antara 30 - 50 ribu jiwa. Hal yang menarik adalah seluruh kawasan perkotaan sedang ini merupakan kawasan perkotaan yang berada pada kawasan pinggiran barat dari Kota Pekalongan, dan tidak satu pun yang berada pada kawasan pinggiran timur.

Keempat kawasan perkotan pada kelompok pertama merupakan kawasankawasan perkotaan yang berlokasi dekat Kota Pekalongan dalam radius sekitar $15 \mathrm{~km}$, yang berlokasi pada jaringan jalan utama yang ada. Kawasan Kedungwuni, yang berlokasi di wilayah Kabupaten Pekalongan, berjarak sekitar $13 \mathrm{~km}$ dan terletak pada koridor jalan regional yang menghubungkan Kota Pekalongan dengan kawasan selatan Kabupaten Pekalongan. Sementara Comal, Ulujami dan Tirto merupakan kawasankawasan yang berlokasi dalam koridor Jalan Nasional Pantura di wilayah Kabupaten Pemalang. Kawasan-kawasan perkotaan ini juga merupakan kawasan-kawasan perkotaan yang memiliki banyak desa perkotaan, yang juga mengalami pertambahan jumlah desa perkotaan yang cukup signifikan.

Sementara itu, enam kawasan perkotaan yang termasuk pada kelompok kedua memiliki pola lokasi yang lebih beragam. Selain memiliki Kawasan Wiradesa, Buaran, dan Wonokerto yang berjarak dalam radius $15 \mathrm{~km}$ dari Kota Pekalongan, kelompok ini juga memiliki Kawasan Bojong yang berjarak sekitar $25 \mathrm{~km}$, serta Kawasan Randudongkal dan Moga yang berjarak masing-masing 65 dan $75 \mathrm{~km}$ dari Kota Pekalongan. Empat kawasan perkotaan yang pertama merupakan kawasan-kawasan yang berlokasi di wilayah Kabupaten Pekalongan dan dua kawasan terakhir berlokasi di wilayah Kabupaten Pemalang yang merupakan kawasan pusat-pusat pelayanan di bagian tengah dan selatan kabupaten tersebut. Tiga kawasan perkotaan di dalam kelompok ini, yaitu Wiradesa, Buaran dab Bojong memiliki jumlah desa perkotaan yang cukup banyak, sementara tiga kawasan lainnya tidak memiliki jumlah desa perkotaan sebanyak ketiga kawasan perkotaan tersebut.

\section{Kawasan Perkotaan dengan Penduduk di bawah 30 ribu Jiwa}

Tabel 3 pada halaman berikut memperlihatkan kawasan-kawasan perkotaan dengan jumlah penduduk yang relatif kecil, yang juga bisa dikelompokkan kepada dua kategori kawasan, yaitu: 11 buah kawasan perkotaan kecil dengan jumlah penduduk antara 15 - 30 ribu jiwa, dan 18 kawasan perkotaan mikro yang terletak dalam 13 kecamatan dengan jumlah pendudik di bawah 15 ribu jiwa. Berbeda dengan kawasankawasan perkotaan pada kelompokkelompok yang berukuran lebih besar yang cenderung turut mengalami proses aglomerasi atau penggabungan dengan-desadesa perkotaan lain yang berada di dalam kecamatannya, kawasan-kawasan perkotaan mikro masih belum mengalami proses serupa di dalam proses perkembangan jumlah desa perkotaan yang ada di dalamnya. Oleh karena itu, terdapat beberapa kecamatan, seperti Siwalan, Subah, Bawang dan Tersono yang memiliki lebih dari satu kawasan perkotaan mikro di dalam wilayah kecamatannya (lihat Tabel 3). 
Tabel 3. Pertumbuhan Kawasan-kawasan Perkotaan Kecil dengan penduduk di bawah 30 ribu jiwa, dari tahun 1990 hingga 2017

\begin{tabular}{|c|c|c|c|c|c|c|c|c|c|c|}
\hline \multirow[b]{2}{*}{ No. } & \multirow[b]{2}{*}{ Kecamatan } & \multirow[b]{2}{*}{$\begin{array}{c}\text { Kawasan } \\
\text { Perkotaan (KP) }\end{array}$} & \multicolumn{2}{|c|}{1990} & \multicolumn{2}{|c|}{2000} & \multicolumn{2}{|c|}{2010} & \multicolumn{2}{|c|}{2017} \\
\hline & & & $\begin{array}{c}\text { Jumlah } \\
\text { Desa }\end{array}$ & $\begin{array}{c}\text { Jumlah } \\
\text { Penduduk } \\
\text { (jiwa) }\end{array}$ & $\begin{array}{l}\text { Jumlah } \\
\text { Desa }\end{array}$ & $\begin{array}{c}\text { Jumlah } \\
\text { Penduduk } \\
\text { (jiwa) }\end{array}$ & $\begin{array}{l}\text { Jumlah } \\
\text { Desa }\end{array}$ & $\begin{array}{c}\text { Jumlah } \\
\text { Penduduk } \\
\text { (jiwa) }\end{array}$ & $\begin{array}{c}\text { Jumlah } \\
\text { Desa }\end{array}$ & $\begin{array}{c}\text { Jumlah } \\
\text { Penduduk } \\
\text { (jiwa) }\end{array}$ \\
\hline 1 & Warungpring $(\mathrm{Pml})$ & KP Warungpring & - & - & - & - & 3 desa & 29,701 & 3 desa & 29,701 \\
\hline 2 & Wonopringgo (Pkl) & KP Wonopringgo & 7 desa & 17,488 & 8 desa & 22,205 & 9 desa & 28,254 & 9 desa & 28,760 \\
\hline 3 & Ampelgading (Pml) & KP Ampelgading & - & - & - & - & 6 desa & 26,852 & 6 desa & 26,852 \\
\hline 4 & Tulis (Btg) & KP Tulis & 4 desa & 8,346 & 4 desa & 8,828 & 9 desa & 22,811 & 9 desa & 23,219 \\
\hline 5 & Karangdadap (Pkl) & KP Karangdadap & 3 desa & 6,678 & 3 desa & 8,013 & 6 desa & 21,309 & 6 desa & 22,728 \\
\hline \multirow[t]{2}{*}{6} & Sragi (Pkl) & KP Sragi & 1 desa & 6,789 & 1 desa & 6,701 & 7 desa & 21,729 & 7 desa & 22,074 \\
\hline & & KP Kalijambe & 1 desa & 3,126 & 1 desa & 3,278 & - & - & - & - \\
\hline 7 & Bandar (Btg) & KP Bandar & 1 desa & 3,701 & 1 desa & 3,729 & 4 desa & 16,525 & 4 desa & 18,003 \\
\hline 8 & Kandeman (Btg) & KP Kandeman & 1 desa & 5,934 & 1 desa & 6,098 & 4 desa & 17,037 & 4 desa & 17,756 \\
\hline 9 & Kajen (Pkl) & KP Kajen & 1 desa & 3,990 & 3 desa & 12,965 & 4 desa & 17,147 & 4 desa & 17,271 \\
\hline 10 & Limpung (Btg) & KP Limpung & - & - & 2 desa & 5,410 & 6 desa & 15,684 & 6 desa & 15,965 \\
\hline 11 & Bantarbolang (Pml) & KP Bantarbolang & 1 desa & 11,061 & 1 desa & 12,287 & 1 desa & 15,372 & 1 desa & 15,372 \\
\hline 12 & Kasesi (Pkl) & KP Kasesi & - & - & - & - & 3 desa & 13,020 & 3 desa & 13,280 \\
\hline 13 & Banyuputih (Btg) & Banyuputih & - & - & - & - & 3 desa & 11,465 & 3 desa & 12,079 \\
\hline \multirow[t]{2}{*}{14} & Siwalan (Pkl) & KP Siwalan & 1 desa & 2,910 & 1 desa & 3,111 & 3 desa & 10,455 & 3 desa & 10,545 \\
\hline & & KP Mejasem & - & - & - & - & 1 desa & 3,419 & 1 desa & 3282 \\
\hline \multirow[t]{2}{*}{15} & Subah (Btg) & KP Subah & 1 desa & 5,008 & 1 desa & 5,256 & 2 desa & 8,109 & 2 desa & 8,852 \\
\hline & & KP Sengon & & & & & 1 desa & 6,909 & 1 desa & 7,489 \\
\hline 16 & Karanganyar (Pkl) & KP Karanganyar & - & - & - & - & 2 desa & 6,329 & 2 desa & 6,450 \\
\hline
\end{tabular}


H. Mardiansjah, P. Rahayu. Perkembangan Kawasan Perkotaan ... 16

\begin{tabular}{|c|c|c|c|c|c|c|c|c|c|c|}
\hline \multirow[t]{2}{*}{17} & Bawang (Btg) & KP Bawang & 1 desa & 4,436 & 1 desa & 4,893 & 1 desa & 5,028 & 1 desa & 5,305 \\
\hline & & KP Sibebek & - & - & - & - & 1 desa & 1,934 & 1 desa & 2,114 \\
\hline 18 & Watukumpul Pml) & KP Watukumpul & - & - & - & - & 1 desa & 5,180 & 1 desa & 5,180 \\
\hline \multirow[t]{2}{*}{19} & Blado (Btg) & KP Blado & 1 desa & 2,146 & 1 desa & 2,584 & 1 desa & 3,987 & 1 desa & 4,410 \\
\hline & & KP Kalipancur & - & - & - & - & 1 desa & 2,218 & 1 desa & 2,474 \\
\hline 20 & Doro (Pkl) & KP Doro & 1 desa & 3,073 & 1 desa & 3,583 & 1 desa & 4,025 & 1 desa & 4,148 \\
\hline 21 & Paninggaran (Pkl) & KP Paninggaran & - & - & - & - & 1 desa & 3,643 & 1 desa & 3,739 \\
\hline \multirow[t]{2}{*}{22} & Tersono (Btg) & KP Rejosari Barat & - & - & - & - & 1 desa & 2,728 & 1 desa & 2,755 \\
\hline & & KP Tanjungsari & - & - & - & - & 1 desa & 3,340 & 1 desa & 2,101 \\
\hline 23 & Reban (Btg) & KP Reban & - & - & - & - & 1 desa & 2,374 & 1 desa & 2,448 \\
\hline 24 & Kandangserang (Pkl) & KP Kandangserang & - & - & 1 desa & 1,337 & 1 desa & 1,363 & 1 desa & 1,369 \\
\hline
\end{tabular}


Pada kelompok kesebelas kawasan perkotaan yang pertama, terdapat kawasankawasan perkotaan yang memiliki jumlah desa perkotaan yang cukup banyak, seperti Kawasan Wonopringgo Kabupaten Pekalongan (Pkl) dann Tulis Kabupaten Batang (Btg) yang masing-masing memiliki sembilan buah desa perkotaan, serta Sragi (Pkl), Ampelgading Kabupaten Pemalang (Pml), Karngdadap (Pkl), dan Limpung (Btg) yang memiliki tujuh atau enam desa perkotaan. Namun pertambahan jumlah desa perkotaan yang terjadi relative kecil bila dibandingkan dengan pertambahan yang dialami oleh kawasan-kawasan perkotaan lain yang lebihbesar. Bahkan, Kawasan Bantarbolang Kabupaten Pemalang (Pml) yang berpenduduk 15.372 jiwa di tahun 2017 tetap hanya memiliki sebuah desa perkotaan hingga saat ini. Diperkirakan, rendahnya pertambahan jumlah desa perkotaan, yang kemudian juga berimplikasi kepada rendahnya pertambahan penduduknya, diakibatkan oleh kondisi lokasi dari kawasankawasan perkotaan ini yang jauh dari Kota Pekalongan dan/atau jaringan jalan utama.

Sementara itu, sebagian besar kawasan perkotaan pada kelompok mikro merupakan kawasan perkotaan yang hanya memiliki satu desa perkotaan saja. Hanya lima kawasan dari 18 kawasan perkotaan mikro yang memiliki tiga atau dua desa perkotaan hingga kini, yaitu Kasesi (Pkl), Banyuputih (Btg) dan Siwalan (Pkl) serta Subah (Byg) dan Karanganyar (Pkl) (lihat Tabel 3).

Sebagian besar dari kawasan-kawasan perkotaan mikro ini merupakan ibukotaibukota kecamatan dari kecamatankecamatan yang berlokasi jauh dari lokasi ibukota kabupatennya dan/atau dari jaringan jalan utama yang ada di wilayahnya. Dalam konteks ini, maka dapat dikatakan bahwa faktor lokasi dan jarak menjadi faktor-faktor yang membawa implikasi pada proses pertumbuhannya. Tabel 3 juga memperlihatkan bahwa sebagian besar yaitu 12 kawasan perkotaan mikro ini juga baru terkategori sebagai kawasan perkotaan sejak tahun 2010, sehingga kawasan-kawasan tersebut bisa dibilang sebagai kawasan perkotaan baru.

\section{SIMPULAN}

Pembahasan di atas memperlihatkan bahwa proses perkembangan kawasan pinggiran dari kota kecil-menengah seperti Kota Pekalongan ini juga telah menjadi suatu proses penting yang harus dicermati di dalam proses urbanisasi di Indonesia. Proses perkembangan di kawasan pinggiran ini tidak saja telah membawa implikasi kepada tumbuh dan berkembangnya kawasan-kawasan perkotaan lain di kawasan pinggiran Kota Pekalongan, tetapi bersama dengan perkembangan Kota Pekalongan sebagai kawasan perkotaan inti/utamanya juga telah membangun sebuah koridor perkotaan besar dengan ukuran jumlah peduduk yang lebih dari satu juta penduduk, sebuah ukuran penduduk yang setara dengan kota-kota besar atau metropolitan.

Selain kawasan-kawasan perkotaan yang bersama Kota Pekalongan membentuk Korodor Perkotaan Pekalongan tersebut, kawasan pinggiran dari Kota Pekalongan juga memiliki sekitar 45 kawasan perkotaan lain dari berbagai ukuran, dari sedang hingga ke mikro. Di dalam konstelasi wilayah dari ketiga kabupaten dimana penggunaan lahannya masih didominasi oleh penggunaan lahan perkotaan, kawasan-kawasan perkotaan tersebut turut membangun kawasan pinggiran Kota Pekalongan menjadi suatu kawasan periurban dengan koridor perkotaan tadi sebagai kawasan perkotaan utama yang didukung oleh kawasan-kawasan perkotaan sedang, kecil dan mikro sebagai kawasan-kawasan yang membangun penetrasi aktivitas perkotaan di dalam lingkungan kawasan pertanian perdesaan yang masih menjadi karakter dominan dari ketiga wilayah kabupaten tersebut.

Bisa dikatakan bahwa proses ini merupakan suatu pengulangan (replikasi) dari proses serupa yang terjadi pada kota-kota besar utama (primate cities) wilayah di Asia Timur dan Selatan, seperti yang disampaikan oleg Ginsburg (1991) dan McGee (1991) sebagai suatu proses urbanisasi pedesaas (urbanization of the countryside) dan juga urbanisasi yang menerus (continuous urbanization) sebagai akibat dari perkembangan ruang ekonomi yang juga 
dihasilkan oleh proses urbanisasi. Penelitian ini ini juga mengkonfirmasi pendapat Tommy Firman (2003) yang mengatakan pertumbuhan melebar dari kota-kota di Pulau Jawa, dimana penelitian ini memperlihatkan fenomena urbanisasi melebar dan mendorong terjadinya perkembangan yang melompat (sprawl) pada kota kecil-menegah di Pulau Jawa, termasuk pada kawasan-kawasan perkotaan kecil yang berada di pinggirannya.

Simpulan lain yang bisa dilihat adalah kondisi perkembangan dari kawasan-kawasan perkotaan di kawasan pinggiran ini sangat dipengaruhi oleh beberapa faktor utama. Faktor lokasi menjadi faktor yang diperkirakan memiliki berpengaruh yang paling besar. Indikasi ini tampak dari kondisi bahwa sebagian besar dari kawasan perkotaan, baik yang terkategori besar maupun sedang berlokasi pada tempat-tempat yang cukup dekat dari Kota Pekalongan dan/atau jaringan Jalan Nasional Pantura, dan sebagian besar dari kawasan perkotaan yang terkategori kecil dan mikro berlokasi jauh dari kedua acuan tersebut. Faktor sejarah fungsi kawasan dalam fungsi administratif juga diperkirakan menjadi faktor yang turut memberi pengaruh signifikan.Indikasi ini tampak dari kondisi bahwa Kawasan Perkotaan Pemalang dan Batang merupakan kawasan-kawasan perkotaan terbesar di wilayahnya adalah kawasan-kawasan yang berfungsi sebagai ibukota kabupaten sejak masa lalu. Kawasan Kajen yang merupakan ibukota Kabupaten Pekalongan bukan menjadi kawasan perkotaan terbesar karena ibukota Kajen merupakan ibukota baru yang baru difungsikan sejak tahun 2001 dengan dilakukan pemindahan ibukota Kabupaten Pekalongan dari Kota Pekalongan ke Kajen. Faktor ketiga yang juga diperkirakan turut memberikan pengaruh signifikan terhadap perkembangan kawasan-kawasan perkotaan tersebut adalah factor sejarah pengelolaan pembangunan wilayah atau yang juga bisa disebut sebagai faktor desentralisasi atau otonomi daerah. Indikasi ini sangat tampak dari besarnya pertambahan desa-desa perkotaan pada masa setelah tahun 2000, atau antara tahun 2000 hingga 2010, terutama pada kawasan-kawasan perkotaan besar dan sedang, dan banyaknya bermunculan kawasan-kawasan perkotaan baru terutama yang berukuran kecil dan mikro pada masa setelah tahun 2000 yang merupakan masa atau era desentralisasi dan otonomi daerah.

\section{REKOMENDASI}

Penelitian ini menrekomendasikan dilakukannya penelitian serupa yang dilakukan paada kota-kota kecil-menengah lain yang berada di Pulau Jawa maupun di luar Jawa agar pemahaman terhadap proses urbanisasi pada kota-kota kecil dan menengah di Indonesia dapat dilakukan secara lebih lengkap dan lebih mendalam. Selain itu, penelitian ini juga merekomendasikan dilakukannya penelitian tentang pengembangan pola kerjasama antar daerah kota dan kabupaten, terutama yang bersebelah-sebelahan dan membentuk suatu kawasan perkotaan yang sama dan masif, di dalan proses pengelolaan pembangunan perkotaannya.

Proses urbanisasi yang melebar dan mendorong terjadinya sprawl pada kota-kota kecil-menengah, termasuk di wilayah kabupaten seperti ini membutuhkan pengelolaan yang tepat dan cermat agar dapat menghindari terjadinya berbagai persoalan yang seringkali juga dibawa oleg proses urbanisasi seperti pertumbuhan yang tidak merata dan periperalisasi wilayah (lihat Tan, 2017 dan Pradoto dkk, 2018), dan bahkan dapat meningkatkan pemanfaatan urbanisasi terhadap pengentasan kemiskinan (lihat Chen dkk, 2019), pengelolaan kawasan hijau termasuk hutan alami yang dimiliki (lihat Sun dkk, 2019), dan peningkatan/penguatan relasi dan interkoneksi fungsi lingkungan antar kawasan di dalam proses urbanisasi (lihat Wang dkk, 2019 dan Yu dan Zhou, 2018).

Oleh karena itu, bagi para pemangku jabatan pengelolaan pembangunan wilayah, termasuk proses urbanisasi di dalamnya, penelitian ini merekomendasikan peningkatan dan pengembangan kapasitas pengelolaan pembangunan perkotaan, termasuk pengembangan kapasitas kerjasama di dalamnya. Rekomendasi ini tidak hanya ditujukan kepada para pemangku jabatan di daerah-daerah kota saja, tetapi juga kepada mereka yang berada di daerah-daerah 
kabupaten, terutama kabupaten-kabupaten yang telah mengalami proses urbanisasi yang cepat seperti kabupaten-kabupaten yang diamati di dalam penelitian ini.

\section{DAFTAR PUSTAKA}

Chen, M., Sui, Y., Liu, W., Liu, H., \& Huang, Y. (2019). Urbanization patterns and poverty reduction: A new perspective to explore the countries along the Belt and Road. Habitat International, 84(November 2018), 1-14. https://doi.org/10.1016/j.habitatint.2018. 12.001

P. Rahayu, P dan Mardiansjah, F.H. 2019. The gowth and distribution of cities in Java dalam A.S Permana, P. Rahayu, H.N.Ismail of Contemporary Urban LIfe and Development p. 1-26, Surakarta, Indonesia UNS Press

Dutta, S., Bardhan, S., \& Bhaduri, S. (2013). Patterns of Urbanization and Environmental Quality in the Context of Indian Cities. Environment and Urbanization Asia, 4(2), 287-299. https://doi.org/10.1177/09754253135107 68

Fahmi, F. Z., Hudalah, D., Rahayu, P., \& Woltjer, J. (2014). Extended urbanization in small and medium-sized cities: The case of Cirebon, Indonesia. Habitat International, 42, 1-10. https://doi.org/10.1016/j.habitatint.2013. 10.003

Firman, T. (2003a). Potential impacts of Indonesia's fiscal decentralisation reform on urban and regional development: Towards a new pattern of spatial disparity. Space and Polity, 7(3), 247271.

https://doi.org/10.1080/13562570320001 69712

Firman, T. (2003b). The spatial pattern of population growth in Java , $1990 \pm 2000$. International Development Planning Review, 25(1), 53-66.

Firman, T. (2017). The urbanisation of Java, 2000-2010: towards 'the island of mega- urban regions.' Asian Population

Studies, 13(1), 50-66. https://doi.org/10.1080/17441730.2016.1 247587

Firman, T., \& Fahmi, F. Z. (2017). The Privatization of Metropolitan Jakarta's (Jabodetabek) Urban Fringes: The Early Stages of "Post-Suburbanization" in Indonesia. Journal of the American Planning Association, 83(1), 68-79. https://doi.org/10.1080/01944363.2016.1 249010

Firman, T., Kombaitan, B., \& Pradono, P. (2007). The dynamics of Indonesia's urbanisation, 1980-2006. Urban Policy and Research, 25(4), 433-454. https://doi.org/10.1080/08111140701540 752

Ginsburg, N. (1991). Extended Metropolitan Regions in Asia: A new spatial paradigm dalam N.Ginsburg, B. Koppel, and T.G. McGee of The Extended Metropolis: Settlement Transition in Asia, pp. 27-46, Honolulu University of Hawai Press

Mardiansjah, F. H. (2013). Urbanisation durable des territoires et politiques de développement urbain en Indonésie.

Mardiansjah, F. H., Handayani, W., \& Setyono, J. S. (2018). Pertumbuhan Penduduk Perkotaan dan Perkembangan Pola Distribusinya pada Kawasan Metropolitan Surakarta. Jurnal Wilayah Dan Lingkungan, 6(3), 215. https://doi.org/10.14710/jwl.6.3.215-233

McGee, T.G. (1971). The urbanization process in the Third World: explorations in search of a theory. London, UK: Bell.

McGee, T.G. (1991). The emergence of desa kota region in Asia: expanding a hyphoteshis dalam N.Ginsburg, B. Koppel, and T.G. McGee of The Extended Metropolis: Settlement Transition in Asia, pp. 3-26, Honolulu: University of Hawai Press

McGee, T.G. (2005). Distinctive urbanization in the peri-urban regions of East and Southeast Asia: Renewing the debate, Jurnal Perencanaan Wilayah dan 
Kota.16.1: 39-55

McGregor, D. Simon, D., Thomson, D. (2006). The peri-urban interface in developing areas: The research agenda. D. McGregor, D. Simon, D.Thompson, The Peri-urban Interface: Approaches to Sustainable NAtural and HUman Resource Use, pp.311-325. New York, USA: Earthscan

Pradoto, W., Mardiansjah, F. H., Manullang, O. R., \& Putra, A. A. (2018). Urbanization and the Resulting Peripheralization in Solo Raya, Indonesia. IOP Conference Series: Earth and Environmental Science, 123(1). https://doi.org/10.1088/1755-

1315/123/1/012047

Prawatya, N. A. (2013). Perkembangan Spasial Kota-Kota Kecil Di Jawa Tengah. Jurnal Wilayah Dan Lingkungan, $\quad 1(1), \quad$ https://doi.org/10.14710/jwl.1.1.17-32

Setyono, J. S., Yunus, H. S., \& Giyarsih, S. R. (2016). the Spatial Pattern of Urbanization and Small Cities Development in Central Java: a Case Study of Semarang-YogyakartaSurakarta Region. Geoplanning: Journal of Geomatics and Planning, 3(1), 53-66. https://doi.org/10.14710/geoplanning.3.1 .53-66

Sun, C., Lin, T., Zhao, Q., Li, X., Ye, H., Zhang, G., Liu, X., \& Zhao, Y. (2019).
Spatial pattern of urban green spaces in a long-term compact urbanization process - A case study in China. Ecological Indicators, 96(August 2017), 111-119.

https://doi.org/10.1016/j.ecolind.2017.09 .043

Tacoli, C. (2006). The earth scan reader in rural-urban linkages. London, UK: Earthscan.

Tan, M. (2017). Uneven growth of urban clusters in megaregions and its policy implications for new urbanization in China. Land Use Policy, 66(April), 7279.

https://doi.org/10.1016/j.landusepol.2017 .04 .032

Wang, J., Xu, C., Pauleit, S., Kindler, A., \& Banzhaf, E. (2019). Spatial patterns of urban green infrastructure for equity: A novel exploration. Journal of Cleaner Production, 238, 117858. https://doi.org/10.1016/j.jclepro.2019.11 7858

Yu, W., \& Zhou, W. (2018). Spatial pattern of urban change in two Chinese megaregions: Contrasting responses to national policy and economic mode. Science of the Total Environment, 634, 1362-1371.

https://doi.org/10.1016/j.scitotenv.2018.0 4.039 